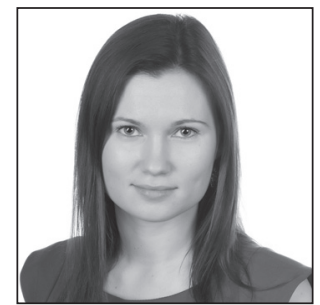

Dina Sõritsa

\title{
The Health-care Provider's Civil Liability in Cases of Wrongful Life: An Estonian Perspective
}

\section{Introduction}

Most parents expect their children to be free from any ailments and, accordingly, seek health-care assistance in order to eliminate risks to the health of their future child, especially where there exists a hereditary illness or the risk of the child being born with a disability. ${ }^{* 1}$ In their choices, the parents are dependent on the information they receive from the health-care provider. However, it should be clear that not every birth of a disabled child can or should be followed by the health-care provider's obligation to compensate for the damages.

Unwanted pregnancy and the birth of a disabled child give rise to several claims that have been recognised in the case law. Perhaps the most controversial is the child's claim of wrongful life, wherein the child alleges the existence of damages through having been born disabled for reason of negligence by the healthcare provider in failing to diagnose or warn about the disability or risk of disability. ${ }^{* 2}$ Even if the presence of negligent conduct of the health-care provider is recognised, there are several obstacles to establishing the harming of an interest and establishing of causation, along with the existence and the extent of damage.

Courts in Europe do not generally satisfy claims of wrongful life. ${ }^{*}{ }^{*}$ The situation is similar in the US, except in some jurisdictions that allow these claims. ${ }^{*}$ In Estonia, case law addressing cases of wrongful life (as well as claims made by parents that arise from unwanted pregnancy and the birth of a disabled child) is completely absent, which makes theoretical analysis of the possible outcome under the Estonian Law of Obligations Act ${ }^{*}$ even more intriguing. This article examines various law systems' arguments as to the

J.K. Mason et al. Law and Medical Ethics, 8th edition. Oxford University Press 2011, p. 338.

2 Because the claims of wrongful life do not involve the disabled child's parents' claims, the latter are not analysed in the present article. Parents' claims arising from an unwanted pregnancy or the birth of a disabled child are regarded, respectively, as claims of wrongful conception (e.g., Lovelace Medical Center v. Mendez, 805 P.2d 603 (N.M. 1991)) and wrongful birth (e.g., Becker v. Schwartz, 386 N.E.2d 807 (N.Y. 1978)). For discussion of wrongful conception and wrongful birth, see, for example, K. Wevers. Prenatal torts and pre-implantation genetic diagnosis. - Harvard Journal of Law \& Technology 24 (2010) /1 (Fall).

3 Nevertheless, there have been successful wrongful-life claims, as in the Dutch case of Kelly Molenaar (Hoge Raad, 18.3.2005, Rechtspraak van de Week 2005, 42) and the French case of Nicolas Perruche (Cass. Ass. Plén., 17.11.2000, JCP G2000, II-10438, 2309).

4 In the US, claims of wrongful life are allowed in California (e.g., Turpin v. Sortini, 643 P.2d 954, 966 (Cal. 1982), New Jersey (e.g., Moscatello v. Univ. of Med. and Dentistry of N. J., 776 A.2d 874, 881 N.J. Super. Ct. App. Div. 2001), and Washington (e.g., Harbeson v. Parke-Davis, Inc., 656 P.2d 483, 495 Wash. 1983).

5 The Law of Obligations Act is available in English via http://www.legaltext.ee/. 
possibility of a child's making of such a claim and surrounding its resolution, with a focus on the existing solutions offered by case law and literature in the US (as an example of solutions under common law) and Germany (whose legal order has greatly affected the development of Estonian civil law).

\section{The damage suffered by the child - the non-existence paradox}

The LOA's $\$ 127$ (1) stipulates that the purpose of compensation for damage is to place the aggrieved person in a situation as near as possible to that in which that person would have been if the circumstances that form the basis for the compensation obligation had not arisen. In wrongful-life cases, were it not for the defendant's negligence, the infant plaintiff would never have existed. The central question here is whether the child has suffered any legally cognisable harm by being brought into existence with a congenital disease or trait. In Germany, the state constitution prohibits classifying the existence of a child as damage. ${ }^{* 6}$ Most of the competent US courts have stated that the child has not suffered a legally cognisable injury. ${ }^{*}{ }^{7}$

The so-called non-existence paradox is one of the main reasons to deny such a claim under the rubric of wrongful life. ${ }^{*}$ As the US courts have stated, the law is not equipped to make such a comparison and there is no rational way to measure non-existence. ${ }^{*} 9$ It is impossible to restore someone to the state of pre-existence, and there is no known comparator for assessment of the difference between the two states at issue. ${ }^{* 10}$ Also, as the Federal Court of Justice of Germany (Bundesgerichtshof, or BGH) has stated, it is impossible to determine whether non-existence is preferable to a life with disability. ${ }^{* 11}$ Undoubtedly, the quality of life of a disabled child is greatly dependent on the severity of the disability. B. Steinbock alleges that in certain cases of severe disability that deprives the child of his most basic interest, it could be said that the child's existence is a life that is not worth living. ${ }^{*} 2$ In the opinion of N. Priaulx, in cases of wrongful life the child is harmed by being brought into existence. ${ }^{*}{ }^{3}$ Several solutions have been proposed to overcome the non-existence paradox, but none of them enables discounting the fact that absent the health-care provider's liability, the child would not have existed.

In Estonia, the Termination of Pregnancy and Sterilisation Act, in $§ 6$ (2) 2), provides for an abortion in circumstances wherein there exists the risk of the child being born with a severe physical or mental abnormality. By stipulating the possibility of making the decision to abort the pregnancy in cases of possible severe health problems of a child at a time when normally abortion is not permitted (i.e., after the 11th week), the possibility of choosing non-life over life in an impaired state could be recognised. ${ }^{*}{ }^{*}$ The proponents of liability for wrongful life state that if the preference for non-existence is permissible in one area of law (i.e., allowing abortion in case of the risk of disability), it may be permitted in another. ${ }^{* 15}$

In the author's opinion, the non-existence paradox is an obstacle that cannot be overcome by the existing legislation. Still, it should not be overlooked that the child's health condition entails extra expenses and

6 Münchener Kommentar zum Bürgerliches Gesetzbuch. Schuldrecht. Allgemeiner Teil. 5. Auflage (München Commentary to German Civil Code. Law of Obligations. General part. 5th Edition). Munich: Verlag C. H. Beck 2007; 'Kind Als Schade' 28.5.1993 BVerfGE 88, 203 Bundesverfassungsgericht (Second Division).

7 Examples: Becker v. Schwartz, 46 N.Y.2d 401 (1978); Gleitman v. Cosgrove, 49 N.J. 22 (1967) 227 A.2d 689.

8 Gleitman v. Cosgrove (ibid.).

9 Example cases: Becker $v$. Schwartz (see Note 7); Procanik v. Cillo, 97 N.J. 339, 478 A.2d 755 (1984).

$10 \quad$ K. Wevers (see Note 2), p. 358.

11 BGH decision BGHZ 86, 240, of 18.1.1983.

12 B. Steinbock. Life before Birth: The Moral and Legal Status of Embryos and Fetuses. New York: Oxford University Press 1992, p. 146.

13 N.M. Priaulx. Conceptualising harm in the case of the 'unwanted' child. - European Journal of Health Law 2002/9, p. 343 DOI: http://dx.doi.org/10.1163/157180902773123969 .

14 Such a deduction is made also by S. Human and L. Mills on the basis of the South African Choice on Termination of Pregnancy Act (92 of 1996), which in their opinion also erodes the public policy argument in cases of wrongful birth and wrongful life. S. Human, L. Mills. The immeasurable wrongfulness of being: The denial of the claim for wrongful life. - Stellenbosch Law Review 21 (2010) /1, p. 69. In South Africa, the claim of wrongful life is not recognised; see Stewart v. Botha, 2007 6 SA 247 (C). Available at http://www.saflii.org/za/cases/ZASCA/2008/84.html (most recently accessed on 19.3.2015).

15 H. Teff. The action for 'wrongful life' in England and the United States. - International and Comparative Law Quarterly 34 (1985) / 3 (July), p. 443 - DOI: http://dx.doi.org/10.1093/iclqaj/34.3.423 . 
the disabled child's birth could have been prevented by means of proper usage of diagnostic methods. ${ }^{* 16}$ Therefore, it is relevant to assess whether the disabled child's expenses and the damage could in principle be compensated for under the Estonian Law of Obligations Act (LOA).

\section{The delictual basis for the health-care provider's liability}

In Estonia, the basis for non-contractual liability in Restatement (Second) of Torts, Section 920 is similar to that in the German Bürgerliches Gesetzbuch (BGB) §823 (1). ${ }^{* 17}$ Under the LOA's §1043, a person (the tortfeasor) who unlawfully causes damage to another person (i.e., the victim) shall compensate for the damage if the tortfeasor is culpable for causing the damage or is liable for causing the damage pursuant to the law. Several lawyers have found that in cases of wrongful life the health-care provider's delictual liability should apply because the birth of a disabled child as a delict corresponds to the traditional meaning of negligence. ${ }^{*} 18$

There are several negligent acts or omissions prior to conception (e.g., the health-care provider negligently advising the parent before conception of the risk of the child inheriting a genetic disability), before implantation (e.g., the health-care provider negligently selecting a damaged embryo for implantation during infertility treatment), or during gestation (e.g., the health-care provider negligently failing to advise the patient that she is carrying a disabled child) that may give rise to a claim of wrongful life. ${ }^{*} 9$ As generally the health-care provider can speak only about the probabilities of the child inheriting a disability, the necessary procedures of prenatal testing do not exclude the possibility of birth of a disabled child. Accordingly, the health-care provider's erroneous act (i.e., medical error or misdiagnosis) should be shown if there is to be a successful claim of wrongful life. ${ }^{*} 20$

In addition to the non-existence paradox, the existence of the child's cognisable interest that has been allegedly harmed by the misdiagnosis is another intriguing question in cases of wrongful life. Though the child's health is damaged, the health-care provider is not liable for the child's disability, a state that would give rise to unlawfulness under the LOA's $§ 1045$ (1) 2) (causing bodily injury to or damage to the health of the victim). ${ }^{* 21}$ Also, there is no harm to the child's personality right (LOA, \$1045 (1) 4) or violation of duty arising from the law (LOA, §1045 (1) 7). ${ }^{* 22}$ Though the Termination of Pregnancy and Sterilisation Act's §6 (2) 2)

16 There are several methods and techniques of prenatal testing, including amniocentesis, ultrasonography, and genetic screening. More information is provided by J.K. Mason et al. (see Note 1), pp. 215-216.

17 Restatement (Second) of Torts, $\$ 920$ states that when 'the defendant's tortious conduct has caused harm to the plaintiff or to his property and in so doing has conferred a special benefit to the interest of the plaintiff that was harmed, the value of the benefit conferred is considered in mitigation of damages, to the extent that this is equitable'. The BGB’s §823 (1) states: 'A person who, intentionally or negligently, unlawfully injures the life, body, health, freedom, property, or another right of another person is liable to make compensation to the other party for the damage arising from this.'

18 W.F. Hensel. The disabling impact of wrongful birth and wrongful life actions. - Harvard Civil Rights-Civil Liberties Law Review 40 (2005), p. 143. Available at http://www.law.harvard.edu/students/orgs/crcl/vol40_1/hensel.pdf143 (most recently accessed on 19.3.2015).

19 I. Kennedy, A. Grubb. Medical Law. London; Edinburgh; Dublin: Reed Elsevier (UK) Ltd 2000, p. 1531. For example, in Turpin $v$. Sortini, the plaintiff alleged that the health-care provider failed to advise her parents that the deafness expressed by an elder sister was hereditary. In Curlender v. Bio-Science Laboratories (165 Cal. Rptr. 477 Cal. C.A. (1980)), the claim was issued on the grounds that the child suffering from Tay-Sachs disease was born in consequence of failure to conduct the relevant genetic tests.

20 In respect of misdiagnosis, the Estonian Supreme Court has stated that, in addition to the claim falling under breach of the contract for provision of health-care services, the patient may have a claim as well under the law of delict, if the breach of contract has resulted in bodily harm or injury (CCSCd 3-2-1-171-10, of 8.4.2011, E. B. v. SA Põhja-Eesti Regionaalhaigla (in Estonian). However, the court has not analysed whether the misdiagnosis as such constitutes a delict. In the author's opinion, the legitimacy of regarding the misdiagnosis as a delict is debatable. It could be difficult to find a duty arising from the law (i.e., to establish unlawfulness under the LOA's $\$ 1045$ (1) 7) that the health-care provider has breached, and it is debatable whether this could be a general duty to maintain safety. Also, the author doubts whether it is sufficient to establish unlawfulness under the LOA’s $\$ 1045$ (1) or (2) (i.e., causing death or bodily harm is presumably unlawful) or there should be additionally violation of duty derived from the law (statutory duty).

21 It should be noted that the LOA’s $\S 1045$ is conditionally based on the BGB’s $\S 823$, its $\S 826$, and the entire body of statements developed in German jurisprudence. P. Varul et al. Võlaõigusseadus III. 8. ja 10. osa (§-d 619-916 ja 1005-1067) Kommenteeritud väljaanne (Law of Obligations III, Parts 8 and 10: A Commentary). Tallinn: Juura 2009, p. 641 (in Estonian).

22 Theoretically, the LOA’s $\$ 1045$ (1) 8) (on intentional behaviour contrary to good morals) sets forth other grounds for presuming the unlawfulness of the health-care provider's act. Therefore, presumably if the health-care provider possesses the essential information, he would disclose the information to the parents. 
allows abortion on account of risk of disability, it does not entail a duty to the parent and cannot constitute a duty to the health-care provider. A woman's liberty to abort does not protect the interest of the foetus. ${ }^{{ }^{2} 3}$ The prevailing view in Germany is that the mother may interrupt her pregnancy insofar as doing so is in her interest. ${ }^{*} 24$ Therefore, it cannot create the foetus's interest in its own termination. As the Bundesgerichtshof has noted, there is no delictual obligation to prevent the birth of a disabled child; nor does the birth of a child violate the legal interests enshrined in the BGB's $§ 823(1){ }^{*}{ }^{* 25}$

It could be concluded that failing to diagnose a child's disability cannot constitute an unlawful act in the meaning of the law of delict, because the law does not provide an obligation for a health-care provider to diagnose a child's disability. Neither can this kind of obligation be derived from the general duty of care. Also, parents cannot have a right protected by law to have a healthy child.

\section{The contractual basis for the health-care provider's liability}

\subsection{The existence of duty to the child under a contract for provision of health-care services}

The LOA contains special provisions regulating the contractual relationship between the patient and the health-care provider. ${ }^{{ }^{2} 26}$ Therefore, it is clear that, for reason of non-existence, the child could not be party to the contract that created the duty of the health-care provider toward the child's mother (or the parents). The possibility of a claim of wrongful life on the basis of the contract for provision of health-care services presumes the existence of a duty toward the child that is derived from the above-mentioned contract.

In the US, a legal duty to a child not yet conceived but foreseeably harmed by the negligent delivery of health-care services to the child's parents has been affirmed - the contractual duty to exercise due care in providing health-care services to the mother confers a correlative right on the expectant mother and on the child who is ultimately born as a third-party beneficiary. ${ }^{* 27}$ On the contrary, under German law, the contract for provision of health-care services concluded by a mother does not prevent the child from living with a disability if this disability could have been prevented only via termination of pregnancy. ${ }^{*} 8$ Germany's Bundesgerichtshof has stated that an obligation arising from the contract between the defendant and the claimant's mother to prevent the birth of the claimant does not have a protective effect toward the child as a claimant. ${ }^{* 29}$ At the same time, there is no duty enforceable by an action in tort to prevent the birth of a disabled child; therefore, any breach of duty could only be derived from the contract between the healthcare provider and the mother. ${ }^{*} 30$

Under the Estonian General Part of the Civil Code Act (CCA), the capacity to have civil rights presumes the existence of passive legal capacity, which begins with the live birth of a human being and ends with that human being's death (CCA, §7 (1) 2)). However, under the CCA’s §7 (3), in the cases specified by

23 Roe v. Wade, 410 U.S. 113 (1973).

24 B. Steinbock (see Note 12).

25 Ibid.

26 Chapter 41 of the Law of Obligations Act stipulates the definition of the contract, the parties' mutual duties, and the prerequisites for liability of providers of health-care services.

27 R. Perry. It's a wonderful life. - Cornell Law Review 93 (2007) /2 (Nov.), p. 392. For instance, in Walker v. Rinck (604 N.E.2d 591 (Ind. 1992)), the court stated that, in addition to the physician's duty to the patient arising from the contract between physician and patient, the physician may owe a duty to a third party who benefits from the consensual relationship where the professional has actual knowledge that the services provided are partly for that person's benefit.

28 P. Gottwald. Vertrag zugunsten Dritter. - F.J. Säcker, R. Rixecker (eds). Münchener Kommentar zum Bürgerliches Gesetzbuch. Schuldrecht. Allgemeiner Teil. 5. Auflage (München Commentary to German Civil Code. Law of Obligations. General part. 5th Edition). Munich: Verlag C. H. Beck 2007, p. 2068.

29 Where the purpose of the contract is to reach a legally permitted goal (i.e., the birth of a child), the health-care provider has the duty of meeting the agreed aim. If the health-care provider commits a medical error, he has to compensate for all economic losses that the contract was intended to prevent (16.11.1993. BGHZ 124, 128 = NJW 1994, 788 VI. Civil Senate (VI ZR 105/92)).

30 B. Steinbock (see Note 12). See also H. Heinrichs. Verpflichtung zur Leistung, in Palandt Bürgerliches Gesetzbuch. 56., neuarbeitete Auflage (Duty of Performance' in Palandt German Civil Code. 56,. Updated edition). Munich: Verlag C. H. Beck 1997, p. 265. 
law, a foetus has passive legal capacity from conception if the child is born alive. This means that the child obtains subjective rights in the state of foetus and these potential rights become actual rights when the child is born alive. ${ }^{*} 31$

It could be alleged that by undertaking prenatal testing parents attempt to protect the future child's interests as well as their own. The contract can be alleged to have a protective effect in the meaning of the LOA's $\S 81$ to the future child if the following prerequisites are met: 1 ) the interests or rights of the child are at risk to the same extent as those of the child's mother, 2) the intent of the child's mother to protect the child's interests can be presumed, and 3) intent to protect the child's interests is identifiable by the healthcare provider (LOA, $\$ 81(1) 1)-3$ )). In such a case, the child as a third party to the contract can in principle make a claim for compensation for the damage caused by the breach of contract (LOA, §81 (2)). ${ }^{*}{ }^{32}$

Consequently, under the LOA, extension of the duty of care is possible and, in principle, a child could rely on the protective effect of the contract between his mother and the health-care provider. The fact that the child was not yet born at the time of formation of the protective duty does not exclude expanding the effect of the protective duty to the child. ${ }^{*} 33$ However, it is doubtful whether the child's interests are linked to the contract with the same intensity as are the interests of the parents.

\subsection{Breach of duties arising from the contract}

In cases of wrongful life, failure to carry out the necessary tests or mistaken interpretation of the results may result in misdiagnosis. Also, the breach of duty might lie in failure to inform the patient, inter alia, of the risks and consequences associated with the provision of health-care service. ${ }^{*} 34$ The breach of the duty to inform the patient is closely linked to the misdiagnosis - if the health-care provider fails, for example, to diagnose the foetus's health condition, he also fails to inform the parents of the future child's health condition. In the absence of sufficient information, the parents are deprived of the possibility to make an informed reproductive choice (i.e., to prevent the birth of a disabled child). ${ }^{*} 5$

Health-care services shall at the very least conform to the general level of medical science at the time the services are provided, and these services shall be provided with the care that can normally be expected of providers of health-care services (LOA, §762). This means that a negative outcome of provision of healthcare services does not amount to a negligent act automatically. Section 770 (1) of the LOA stipulates that providers of health-care services are liable only for the wrongful breach of their own obligations, particularly for errors in diagnosis and treatment and for violation of the obligation to inform patients and obtain their consent. The Estonian Supreme Court has stated that performance of health-care services below the general level of medical science should be regarded as medical error and affirmed the health-care provider's liability under contract law in the case of misdiagnosis. ${ }^{*} 36$

The risk of physical or mental abnormality justifies termination of pregnancy even after the 11th week, according to the Termination of Pregnancy and Sterilisation Act, $\$ 6$ (2) 2). The doctor should be aware of the risk that the initial diagnosis is mistaken and consider the option of referring the patient for specialist investigation. The LOA’s $\$ 762$ explicitly stipulates that the provider of health-care services shall refer a patient to a specialist or involve a specialist in the treatment of the patient if this is necessary. Whereas the protective effect on the child through the contract between his mother and the health-care provider can be

31 See P. Varul's comment 3.6 on §7 of P. Varul et al. Tsiviilseadustiku üldosa seadus (The General Part of the Civil Code Act). Tallinn: Juura 2010 (in Estonian).

32 On the doctor and patient's legal relationship in German law, see W. Uhlenbruck. Die Rechtsbeziehungen zwischen Arzt und Patient (The legal relationship between the doctor and patient) - A. Laufs, W. Uhlenbruck. Handbuch des Arztrechts (Handbook of Medical Law). Munich: C. H. Beck, 1992, pp. 221-271.

33 I. Kull et al. Võlaõigus I. Üldosa Juura (Law of Obligations I: General part), 2004, p. 446 (in Estonian).

34 Section 766 (1) of the LOA explicitly prescribes that the health-care provider shall inform the patient of the results of examination of the patient, the state of the patient's health, any possible illnesses and the development thereof, the nature and purpose of the health-care services provided, and the risks and consequences associated with the provision of such healthcare services and of other available and necessary health-care services. Under the second section of the same provision, the health-care provider shall, at the request of the patient, submit the specified information in a form that can be reproduced in writing.

35 Hickman v. Group Health Plan, Inc., 396 N.W.2d 10, 17 (Minn. 1986).

36 E. B. v. SA Põhja-Eesti Regionaalhaigla (see Note 20). 
affirmed (see Subsection 4.1, above), the child's claim can rely on misdiagnosis or on breach of the duty to inform the patient.

\subsection{Causation}

Even if it could be alleged that the child has been harmed by being brought into existence and has suffered the damage as a consequence, the question of causation poses another obstacle to affirming the claim.

The expectant parents' discretion is of great importance in the process of establishing causation. A causal relationship between the health-care provider's negligence and the birth of a disabled child is present if the parents would have decided to avoid procreation had they possessed the information about the future child's possible disability. However, it could be difficult or even impossible to show that the parents would have decided not to conceive the child. ${ }^{*} 7$ It has been proposed that the action should be based on the health-care provider's unfulfilled promise that the child would be born without a certain defect. This solution leads to liability under contract law. ${ }^{*} 38$ Therefore, it should be stressed that, as a rule, a provider of health-care services shall not promise that a patient will recover or that an operation will be successful. ${ }^{*} 39$ The promise of a positive outcome is even more doubtful with regard to the question of the future child's health condition, which can generally be addressed only in terms of the probability of occurrence of a certain trait. In any case, evaluation of the standard of the health-care provider's performance is needed. The duty to carry out prenatal testing as such does not bring into being a promise to predict the future child's health condition.

Under the LOA ( $\$ 127$ (4)), a person shall compensate for damage only if the circumstances on which the liability of the person is based and the damage caused are related in such a manner that the damage is a consequence of the circumstances (causation must exist) (i.e., the conditio sine qua non test). In cases of medical error, causation between the damage and the medical error or misdiagnosis is presumed if the medical error is established and the patient develops a health disorder that probably could have been avoided by means of ordinary treatment (LOA, $\$ 770$ (4)). In the author's opinion, the LOA's $\$ 770$ (4) cannot be applied in cases of wrongful life, because the health disorder of the child (i.e., disability) cannot be avoided through ordinary treatment. In these cases, the only way to avoid the child's disability is abortion. Therefore, evaluation of the existence of a causal link necessitates juxtaposing the child's life inclusive of disabilities with the state in which the child would have been if the health-care provider had not erred in the prenatal testing - i.e., not having being born. As is stated above (in Section 1), such a comparison cannot be made. Consequently, it is debatable whether a causal relationship between the health-care provider's medical error or misdiagnosis and the damage caused by the birth of a disabled child could be established.

\subsection{Fault}

Fault is another prerequisite for the health-care provider's contractual liability; i.e., he must have breached the obligation culpably (LOA, §770 (1)). In a similarity to the BGB's §278 (2), §104 (3) of the LOA stipulates that a person is careless if he fails to exercise necessary care. The prerequisite for the health-care provider's negligence is met only if his performance is substandard (LOA, §762); the negative outcome as such should not be deemed to bring about liability. The health-care provider's standard of care is higher than the ordinary standard of care that is expected from a person in everyday life. This professional standard of care has also been affirmed in the US. ${ }^{*} 40$ The Estonian Supreme Court has stated that the health-care provider's standard of care must be established as commensurate with the behaviour of an educated and experienced physician in the corresponding field in the same situation. ${ }^{*} 41$ This means that the circumstances of the breach of contractual duty should be evaluated and if an educated and experienced physician in the

37 R. Perry suggests that this situation may be resolved by a variation of the loss-of-chance doctrine. The likelihood that the parents would have decided to procreate without regard for the risk of the future child's disability would not disclaim the child's right of action under wrongful life, but it would affect the estimation of damages. See Note 27, above, p. 381.

38 R. Perry refers to Hawkins v. McGee. Ibid., pp. 381-382.

39 Also explicitly stipulated in the LOA's $\$ 766$ (2).

40 D.B. Dobbs. Torts and Compensation: Personal Accountability and Social Responsibility for Injury, second edition (American Casebook Series). St. Paul, Minnesota: West Publishing Co. 1993, p. 362.

41 CCSCd 3-2-1-78-06, of 3.10.2006, H. M. v. AS V., para. 12 (in Estonian). 
corresponding field would have acted in the same way as the defendant, the medical error or misdiagnosis is excusable. ${ }^{*} 42$

The posterior evaluation of conformity to the professional standard of care should be based on the standard at the time of provision of the health-care services and not consider the development of treatment methods since. ${ }^{* 43}$ Departing from the general treatment methods of the corresponding field does not necessarily constitute a negligent act, but in the event of a dispute the health-care provider should be able to justify the treatment method selected and prove its soundness. ${ }^{*} 44$ According to the LOA's $§ 763$ (1), a method of prevention, diagnosis, or treatment that is not generally recognised may be used only if conventional methods are not likely to be as effective, the patient is informed of the nature and possible consequences of the method, and the patient has granted consent to the use of the method. Consequently, the law provides for the possibility of departing from the general standard of care of the health-care provider (LOA, §762). ${ }^{* 45}$ If necessary, expertise may be called upon for evaluation of the soundness of departure from the general treatment methods. ${ }^{*} 6$

If doing so is necessary, a provider of health-care services shall refer a patient to a specialist or involve a specialist in the treatment of the patient (LOA, \$762). This seems especially essential in cases of interpretation of genetic tests, in light of the possibility of speaking only about probabilities. ${ }^{*} 47$ If unjustified departure from the professional standard of care is established, the health-care provider's fault is absent only in the event of force majeure (LOA, $\$ 103$ (2)). In consideration of the rarity of cases of force majeure, the healthcare provider's fault could generally be affirmed if medical error or negligent misdiagnosis is established.

\section{The scope of the claim}

\subsection{Compensable damage}

In the US, only extraordinary expenses related to the treatment and studies that follow directly from the child's disability are awarded in cases of wrongful life. ${ }^{*} 48$ Non-pecuniary damages (e.g., damages for emotional distress) are not granted to the parents or the disabled child. ${ }^{*} 9$ It should be noted that, unlike in, for instance, Curlender $v$. Bio-Science Laboratories, in Turpin $v$. Sortini the court rejected the claim for general damages (made on grounds of being deprived of the fundamental right of a child to be born as a whole, functional human being) and awarded the child compensation for the extraordinary expenses of special teaching, training, and hearing equipment.

In Estonia, if the above-mentioned prerequisites for the health-care provider's liability are met, the child's extraordinary expenses could be subject to compensation. Under the LOA, specifically §101 (1) 3), in the event of non-performance (i.e., failure to perform or defective performance) by an obligor, the obligee may file a claim for damages. According to the LOA's $\S 130$ (1), the person under obligation shall compensate the aggrieved person for the expenses arising from health damage or bodily injury, including expenses arising from the increased needs of the aggrieved person, total or partial incapacity to work, and the decrease in

42 I. Luik-Tamme, K. Pormeister. Kas süü tervishoiuteenuse osutaja lepingulise vastutuse eeldusena on iseseisev või sisutühi kontseptsioon? (Is the Fault as a Prerequisite of the Health-care Provider's Liability an Independent or an Empty Conception?). - Juridica 2014/X, p. 772 (in Estonian).

43 A. Nõmper, comment 3.1 on the LOA’s $\$ 762$, in P. Varul et al. (see Note 21), p. 300.

44 J.V. McHale, J. Tingle. Law and Nursing, second edition. Edinburgh: Elsevier Science Limited 2002. Available at http:// books.google.com/books?id=79CKyGXkybQC\&pg=PA40\&dq=Loss+of+chance\&lr=\#PPA28,M1 (most recently accessed on 19.3.2015).

45 A. Nõmper, comment 1 on the LOA’s §763, in P. Varul et al. (see Note 21), p. 301.

46 The evaluation of the quality of provision of health-care services in Estonia is provided by the expert committee on quality of health services (under the Health Services Organisation Act, $\$ 50^{2}$ (1)). In a contrast to German quality-expert committees, the Estonian committees do not resolve the disputes between the health-care provider and the patient. For more information about German health-care service-quality expert committees, see M.S. Stauch. Medical malpractice and compensation in Germany. - Chicago-Kent Law Review 86 (2011) /3.

47 The health-care provider's fault in the form of gross negligence was affirmed in case No. 2-05-2059, on the grounds that the general practitioner failed to refer the patient to a cardiologist (Harju County Court, V.S. v. E.P. 29.2.2008 (in Estonian)).

48 K. Wevers (see Note 2), p. 266. See, for instance, Turpin v. Sortini, 182 Cal. Rptr. 377 (1982); Procanik v. Cillo, 97 N.J. 339 , 478 A.2d 755 (1984); Harbeson v. Parke-Davis, Inc., 656 P.2d 483, 495 (Wash. 1983).

49 J.T. Stein. Backdoor eugenics: The troubling implications of certain damages awards in wrongful birth and wrongful life claims. - Seton Hall Law Review 40 (2010), p. 1157. 
income or deterioration of future economic potential. While non-pecuniary damage is difficult to measure, pecuniary damages can be established precisely. As the disability does not disappear when the child reaches adulthood, the disabled child's medical expenses should be recovered further upon reaching of the age of majority. ${ }^{*} 0$

In Procanik $v$. Cillo, the court emphasised that recovery of the cost of extraordinary medical expenses is possible for either parents or the infant, but not both. In Turpin $v$. Sortini, the court specified that if the parents have made a recovery via a wrongful-birth suit, the child should recover only special costs incurred during his adulthood through a wrongful-life suit, to avoid double-counting. ${ }^{* 1}$ The aggrieved person should not be placed in a position better than that he was in before the infliction of damage, and compensation for the damage should not entail the unjust enrichment of the victim (LOA, §127 (5)). In the author's opinion, the argument that the child's damages are recovered under the parents' wrongful-birth claim does not exclude the child's claim made on the basis of wrongful life. The partial overlap of the claims affects the extent of the damage and not the grounds for compensation.

\subsection{Limits to compensation for the damage}

In a similarity to what is found in German civil law, the principle of complete compensation under $\$ 127$ (1) of the LOA is limited. The purpose of the breached duty (LOA, $\$ 127(2))$ and the foreseeability of the damage (LOA, §127 (3)) should be taken into account. ${ }^{* 52}$ Among the limits to the compensation for damage, those related to the benefits of life are the ones discussed most often in cases of wrongful-life claims. Any gain received by the injured party shall be deducted from the compensation for the damage unless deduction is contrary to the purpose of the compensation (LOA, $\$ 127(5)$ ). In the US, the value of the benefit conferred is also considered in mitigation of damages. ${ }^{*} 3$

In Turpin $v$. Sortini, the court stated that the fact that the child has obtained a physical existence with the capacity both to receive and give love and pleasure and to experience pain and suffering should be treated as a benefit that should be offset against compensable damage. ${ }^{*} 54$ As W.F. Hensel has pointed out, while courts emphasise the inherent benefits of rearing a healthy child, many courts ignore these benefits if a child is born with a genetic defect. ${ }^{*} 5$

The Estonian Supreme Court has stated that if improvement of the health condition through compensation for the damages is not reasonably possible without raising of the aggrieved person's health condition to a better level than it exhibited before the infliction of damage, the case could be regarded as involving unsolicited enrichment. In such case, the benefit from improvement of the victim's health due to reimbursement cannot be counted off the compensation that the victim is entitled to.. Otherwise, it would be inconsistent with the LOA's Section 130 (1) and the aim of eliminating the negative consequences for the victim. ${ }^{*} 6$ Analogously, in the case of wrongful life, the life as a benefit cannot be deducted from the compensation for

$50 \quad$ Harbeson v. Parke-Davis, Inc., 656 P.2d 483, 495 (Wash. 1983).

51 M. Strasser. Wrongful life, wrongful birth, wrongful death, and the right to refuse treatment: Can reasonable jurisdictions recognize all but one? - Missouri Law Review 64 (1999) /1 (Winter), pp. 849-850.

52 The person who has breached the contract is not regarded as responsible for the kind of damage the arising of which the performance of the contract was not intended to prevent (E. B. v. SA Põhja-Eesti Regionaalhaigla, as cited in Note 20). Subsections 2 and 3 of the LOA’s $§ 127$ therefore enable disregarding these negative consequences of the breach of contractual obligations that are in causal relation to the breach of the contract but are extraordinary in the view of a reasonable person (CCSCd 3-2-1-53-06, 26.9.2006, A.S. v. AS E. - RT III 2006, 33, 283 (in Estonian)).

53 Restatement (Second) of Torts states, in $\$ 920$ (1979), '[w] hen the defendant's tortious conduct has caused harm to the plaintiff or to his property and in so doing has conferred a special benefit to the interest of the plaintiff that was harmed, the value of the benefit conferred is considered in mitigation of damages, to the extent that this is equitable. However, under the benefit rule, the damages to the plaintiff's interest can be offset only by benefits received by that same interest' (in comment b).

54 Turpin v. Sortini, 643 P.2d 954, 966 (Cal. 1982).

55 I. Kennedy, A. Grubb (see Note 19), p. 154. Also, S.R. Fueger has stated that the distinction between wrongful-life and wrongful-pregnancy claims is unjustifiable. She alleges that the focus should be on the duty owed to the plaintiff, rather than on the victim. For example, in Hickman v. Myers (632 S.W.2d 869, 870 (Tex. Ct. App. 1982)), it was discussed that the benefits of parenthood are one of the reasons to disallow claims of wrongful pregnancy. However, such a rationale is not used for refusing compensation for damages in cases of wrongful-life claims. For further discussion, see S.R. Fueger. The unexamined life is not worth living... or is it? Preserving the sanctity of life in American courtrooms. - Southern Illinois University Law Journal 33 (2009) /Spring, pp. 588-589. 
the child's extraordinary expenses. For a disabled child, being alive could be regarded as unsolicited enrichment that he actually aimed to avoid.

\section{Conclusions}

While the Estonian Termination of Pregnancy and Sterilisation Act’s $\$ 6$ (2) 2) provides for an abortion in circumstances wherein there exists the risk of a child being born with a severe physical or mental abnormality, it could be concluded that the child himself is unlikely to have a successful claim under the wrongful-life rubric. The obstacles in overcoming the non-existence paradox as well as problems in establishing the prerequisites for the health-care provider's civil liability on a delictual or the contractual basis lead to the assertion that satisfying these claims in Estonian courts (similarly to German and US courts) would be unlikely.

Though cases of claims of wrongful life (and of wrongful conception and wrongful birth) have not yet reached the courtroom, there is a high probability that the courts would not regard the child's disability as damage that should be compensated for by the health-care provider, even if the health-care provider has acted negligently. 